\title{
HuKuMAN BAgI PELAKU TINDAK PIDANA Pencurian Dengan KeKerasan
}

\author{
Ahmad Syarif Abdillah Jl Tirto Dusun Tanjungsari Desa \\ syarifabdillah@gmail.com $\quad$ Randuboto RT: 03 RW 04
}

\begin{abstract}
This paper provides an overview of Islamic criminal law against the decision of the District Court of Sidoarjo No: 832/Pid.B/2012/PN.Sda on crime of theft with violence. The research found that the consideration of judge which sentenced by the District Court of Sidoarjo to the defendant has been based on of the elements contained in the Criminal Code in the Republic of Indonesia. The perpetrator of crime of theft with violence was sentenced for 2 (two) years. The decition of the District Court of Sidoarjo No: 832/Pid.B/2012/PN.Sda is on crime of theft with violence. According to Islamic criminal law it can be categorized as jarîmah hirâbah, so defendant is convicted with legal punishment (ta'zîr) and submitted to ulil amri (judge). Kinds of legal penalty can be a death sentence, imprisonment, exclusion, crucifixion, flagellation, and threat. In Indonesia, theft with violence is banned because it disturbs and causes fear of the public.
\end{abstract}

Keywords: Penalty, criminal act, theft, violence.

\begin{abstract}
Abstrak: Tulisan ini membahas tentang tinjauan hukum pidana Islam terhadap putusan Pengadilan Negeri Sidoarjo No: 832/PID.B/2012/PN.Sda tentang kasus tindak pidana pencurian dengan kekerasan. Hukuman yang diberikan hakim Pengadilan Negeri Sidoarjo kepada terdakwa berdasarkan pertimbangan unsur-unsur yang ada pada Kitab UndangUndang Hukum Pidana di Republik Indonesia. Pertanggungjawaban pidana bagi pelaku tindak pidana pencurian dengan kekerasan yang dijatuhi hukuman yang dijatuhkan pada diri para terdakwa adalah hukuman pidana penjara selama 2 tahun. Putusan Pengadilan Negeri Sidoarjo No:832/PID.B/2012/PN.Sda tentang tindak pidana pencurian dengan kekerasan. Menurut hukum pidana Islam dapat dikategorikan dalam jarîmah hirâbah, sehingga terdakwa dihukum ta'zîr, di mana hukuman tersebut diserahkan kepada ulil amri (hakim). Macam hukuman ta'zir dapat berupa hukuman mati, penjara, pengucilan, penyalipan, dera, dan ancaman. Pencurian dengan kekerasan tidak diperbolehkan di Indonesia karena meresahkan masyarakat dan menimbulkan ketakutan serta ketidakyamanan.
\end{abstract}

Kata Kunci: Hukuman, tindak pidana, pencurian, kekerasan. 


\section{Pendahuluan}

Manusia yang telah diciptakan oleh Allah swt sebagai makhluk sosial, dalam kehidupannya sehari-hari, ia tidak akan mampu mandiri tanpa kehadiran orang lain. Kehidupan semacam ini kemudian dikenal dengan istilah hidup bermasyarakat. ${ }^{1}$ Dalam hidup bermasyarakat, seseorang dengan secara sadar atau tidak melakukan hubungan satu sama lain, sesuai dengan kepentingan mereka masing-masing. Karena dalam kehidupan ini, kepentingan seseorang dengan lainnya tidak mesti sama, maka sering terjadi benturan-benturan yang menyebabkan berkurangnya keharmonisan dalam hubungan bermasyarakat. Bahkan tidak jarang terjadi perselisihan yang sangat sengit, yang berakibat saling membunuh satu sama lain. Dengan adanya benturan semacam itulah timbul juga kejahatan-kejahatan yang dampaknya tidak hanya merugikan diri sendiri atau pelaku tapi juga korban dan masyarakat luas.

Keharmonisan dan kesejahteraan bersama, dalam rangka mencapai keinginan masing-masing pihak, maka manusia membuat aturan-aturan yang disepakati bersama. Aturan-aturan itu harus dipatuhi dan dijunjung tinggi, dan inilah sebenarnya yang disebut hukum. Agar hukum tersebut dapat berlangsung terus menerus, dan diterima oleh seluruh anggota masyarakat, maka ia harus sesuai dan tidak bertentangan dengan asas-asas keadilan masyarakat, dimana hukum itu berlaku.

Tindak pidana kejahatan di samping sebagai masalah kemanusiaan, juga merupakan masalah sosial, karena banyak usaha penanggulangannya, salah satunya adalah memakai hukum. ${ }^{2}$ Peraturanperaturan tentang hukum pidana yang berlaku di Indonesia, pada dasarnya bukan ciptaan bangsa Indonesia sendiri.Kitab Undang-Undang Hukum Pidana atau KUHP, yang diberlakukan di Indonesia sejak Januari 1918, adalah merupakan asas konkordansi dari Hukum Pidana Nasional Negeri Belanda (Wetbock Van Strafrecht Nederlandsch Indie) $1886 .{ }^{3}$ Sejak adanya Undang-Undang Tahun 1946 no. 1 tentang Peraturan Hukum Pidana, bagi seluruh rakyat Indonesia, peraturanperaturan tersebut direvisi dengan diadakan perubahan dan penambahan, yang tersusun dalam sebuah buku induk. Buku induk itu

\footnotetext{
${ }^{1}$ Marpaung Leden, Asas Teori Praktik Hukum Pidana (Jakarta: Sinar Grafika, 2008), 1. 2Prodjodikoro, Asas-Asas Hukum Pidana di Indonesia (Bandung: Eresco, 1986), 13.

${ }^{3}$ Zainal Abidin, Hukum Pidana 1 (Jakarta: Sinar Grafika, 1995), 64.
} 
pada akhirnya dikenal dengan Kitab Undang-Undang Hukum Pidana (KUHP). ${ }^{4}$

Kenyataan tersebut tidak dapat dipungkiri, bahwa sebenarnya perundang-perundangan tentang hukum yang berlaku di Indonesia masih banyak meniru dari Kitab Undang-Undang Hukum Pidana yang lahir pada masa penjajahan Hindia Belanda.

Akhir-akhir ini, hampir dalam setiap media masa dan media cetak memberitahukan bahwa di kota A, di kampung B, atau di jalan C, terjadi pencurian-pencurian, baik bersenjata atau pun tidak, sekian rupiah dirampok, pemiliknya dianiaya, ${ }^{5}$ bahkan dibunuh, contoh kasus bahwa terdakwa Sugik alias Koplak dan terdakwa Buamat pada hari Minggu tanggal 07 Oktober 2012 sekitar jam 01.15 WIB atau setidak-tidaknya pada waktu lain Kabupaten Sidoarjo, atau setidak-tidaknya pada tempat lain yang masalah temasuk dalam daerah hukum Pengadilan Negeri Sidoarjo yang berwenang untuk memeriksa dan mengadili terdakwa, telah mengambil suatu barang berupa 1 unit Sepeda Motor Honda Supra Vit warna orange hitam Nopol W-6072-NV yang sama sekali atau sebagian kepunyaan orang lain yaitu milik saksi Khoirul Anwar, dengan maksud untuk memiliki barang itu dengan melawan hukum, yang didahului, disertai dan diikuti dengan kekerasan atau ancaman kekerasan, terhadap orang dengan maksud untuk mempersiapkan atau mempermudah pencurian, atau dalam hal tertangkap tangan untuk memungkinkan melarikan diri sendiri atau peserta lainnya, atau untuk tetap menguasai barang yang diambil, yang dilakukan pada waktu malam di jalan umum, yang dilakukan oleh dua orang atau lebih secara bersekutu.

Kasus di atas bisa digambarkan betapa ketertiban, ketentraman, kenyamanan harta benda dan jiwa masyarakat secara umum menjadi terganggu, dan kecemasan menyelinap dalam hati semua orang.Latar belakang aksi ini adakalanya bermotif ekonomi, adakalanya bermotif politik, aksi kejahatan yang bertendensi kepentingan ekonomi melahirkan tindakan-tindakan perampok baik dalam rumah maupun diperjalanan.Sedangkan yang bertendensi politik, kejahatannya berbentuk perlawanan terhadap peraturan perundang-undangan yang

\footnotetext{
${ }^{4}$ Moeljatno, Kitab Undang-Undang Hukum Pidana (Jakarta: Bumi Aksara, 1990), 5.

${ }^{5}$ Marpaung Ledeng, Tindak Pidana terhadap Nyawa \& Tubuh, 53.
} 
berlaku, dengan meelakukan gerakan-gerakan kekacauan dan mengganggu ketentraman umum).

Indonesia sebagai negara yang mayoritas penduduknya bergama Islam akan tetapi undang-undang pidana yang dipakai bukanlah undangundang pidana Islam, melainkan undang-undang pidana peninggalan Belanda yang telah dinasionalkan dan sampai saat ini masih menjadi pedoman utama para penegak hukum dalam menegakkan keadilan, juga meamandang perbuatan kejahatan semacam itu dapat dapat meresahkan masyarakat, tidak manusiawi, dan tidak berperadaban.

Ketentuan hukum pidana Islam, tindak pidana semacam itu dikenal dengan istilah al-hirâbah, ${ }^{6}$ al-hirâbah menurut al-Qur'an merupakan suatu kejahatan yang gawat. Dilakukan oleh sekelompok atau seorang yang bersenjata, menyerang seorang musafir atau orang-orang yang berjalan di jalan raya atau di tempat manapun mereka berada dengan cara kekerasan, paksaan, atau tidak, di mana si korban berusaha lari untuk mencari pertolongan. al-Qur'an menyebutnya dengan suatu peperangan melawan Allah dan RasulNya, dan merupakan usaha untuk menyebar kerusuhan di atas dunia, mengadakan kekacauan, penumpahan darah, perampasan harta, mengoyak kehormatan, merusak tanaman, peternakan, citra agama, akhlaq, ketertiban umum, dan undang-undang, baik gerombolan itu terdiri dari orang Islam maupun kafir zimmiy atau kafir harbiy.

"Sesungguhnya pembalasan terhadap orang-orang yang memerangi Allah dan Rasul-Nya dan membuat kerusakan di muka bumi, hanyalah mereka dibunuh atau disalib, atau dipotong tangan dan kaki mereka dengan bertimbal balik, atau dibuang dari negeri (tempat kediamannya).Yang demikian itu (sebagai) suatu penghinaan untuk mereka di dunia, dan di akhirat mereka beroleh siksaan yang besar."

Pelanggaran tindak pidana hirâbah dalam hukum pidana Islam, merupakan suatu istilah dengan pengertian pembegalan atau perampokan yang cenderung menyangkut masalah kejahatan jiwa dengan delik-delik yang sekarang ini ada serta persamaannya dalam KUHP, namun sangat jelas sekali perbedaannya dalam sanksi hukum dan penerapannya.

\footnotetext{
${ }^{6}$ Ahmad Wardi Muslich, Hukum Pidana Islam (Jakarta: Sinar Grafika, 2005), 93.

${ }^{7}$ Departemen Agama RI, Al-Qur'an dan Terjemahannya.
} 
Secara umum tujuan hukum adalah menjamin adanya suatu kepastian hukum dalam masyarakat, dan mencegah agar setiap orang tidak menjadi hakim atas dirinya sendiri. Di dalam ajaran Islam, hukum bertujuan menciptakan kemaslahatan dan kesejahteraan umat sehingga akan merasakan kebahagiaan dalam kehidupan dunia ini maupun di akhirat nanti.

Pelaku pelanggaran tindak pidana hirâbah dalam hukum pidana Islam, sangat berat sanksinya baik di kehidupan dunia maupun di akhirat, sebab dampak yang ditimbulkan sangat buruk dan keji terhadap kehidupan manusia yang mana penilaian itu tentu saja berbeda dengan pandangan KUHP yang dalam hal ini termasuk dalam pasal 365 ayat (2) yang dijatuhi hukuman maksimal 12 tahun penjara ${ }^{8}$, sebab di samping hukum ini dibuat berdasarkan kemampuan juga kehendak dan pengalaman hidup manusia itu sendiri. Sedangkan hukum pidana Islam, hukumnya dibuat oleh Allah swt, Pencipta manusia, dengan demikian hukumnya pun berbeda walaupun perbuatannya sama.

Berangkat dari hal di atas, dalam penulisan ini penulis hendak menggambarkan Pertimbangan Hakim Pengadilan Negeri Sidoarjo dalam mengambil putusan terkait mengenai masalah tentang pencurian dengan kekerasan dan sanksi hukum yang diberikan pada pelaku tindak pidana kejahatan ini dengan membandingkan KUHP dan hukum pidana Islam.

\section{Pencurian dengan Kekerasan dalam KUHP}

Pencurian dengan kekerasan merupakan salah satu persoalan yang serius yang ada di Indonesia. Dalam arti kalimat pencurian dengan kekerasan dapat disebut juga dengan perampokan untuk istilah awamnya. Pencurian dengan kekerasan dalam hukum positif adalah pencurian yang didahului, disertai, atau diikuti oleh kekerasan atau ancaman kekerasan terhadap seseorang pasal 365 ayat (1) KUHP, karena didalam pidana tersebut terdapat unsur kekerasan, sebab yang dilakukan oleh si pelaku adalah:

a. Memaksa orang lain dengan kekerasan atau ancaman.

b. Supaya orang itu memberikan sesuatu baranag yang sama sekali atau sebagian milik orang itu atau milik orang lain.

c. Supaya orang itu membuat utang atau menghapus utang.

\footnotetext{
${ }^{8}$ Waluyo Bambang, Pidana dan Pemidanaan (Jakarta: Sinar Grafika, 2000), 16.
} 
d. Dengan maksud agar menguntungkan dirinya sendiri atau diri orang lain dengan melawan hukum. ${ }^{?}$

Arti memaksa adalah melakukan tekanan pada barang yang sedemikian rupa, sehingga orang itu mau melakukan sesuatu yang berlawanan dengan kehendaknya sendiri. ${ }^{10}$ Mengenai arti barang adalah sesuatu benda yang berwujud seperti uang, pakaian, perhiasan dan sebagainya termasuk juga binatang, dan benda-benda yang tidak berwujud, misalnya aliran listrik, dan sebagainya.

Sedangkan mengenai arti melakukan kekerasan adalah menggunakan tenaga atau kekuatan jasmani sekuat mungkin secara tidak sah, misalnya dengan cara memukul dengan tangan, atau dengan segala macam senjata, menyepak, menendang, dan sebagainya yang menyebabkan orang yang terkena tindakan kekerasan itu merasa sakit.

\section{Pencurian dengan Kekerasan dalam Perpektif Fiqh}

Secara bahasa hirâbah adalah bentuk masdar, sedangkan kata kerjanya berasal dari kata haraba (حَرَب) yang berarti memerangi. Pengertian asli haraba (حَرَبَ) adalah menyerang dan menyambar harta lawannya, yang dimaksud hirâbah menurut Abdul Qadir Audah adalah

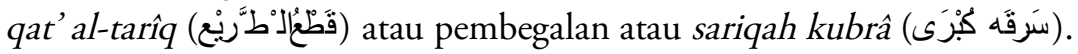

berasal dari kata harb yang artinya perang. Menurut buku Fiqh Sunnah jilid 9 karya Sayyid Sabiq, hirâbah adalah keluarnya gerombolan bersenjata di daerah Islam untuk mengadakan kekacauan, penumpahan darah, perampasan harta, mengoyak kehormatan, merusak tanaman, peternakan, citra agama, akhlak, ketertiban dan undangundang baik gerombolan tersebut dari orang Islam sendiri maupun kafir zimmiy atau kafir harbiy. ${ }^{11}$

Penggunaan kata pencurian untuk pembegalan adalah dalam arti majâz, bukan dalam arti yang hakikat, sebab pencurian adalah mengambil harta secara sembunyi-sembunyi sedang pembegalan adalah mengambil harta dengan terang-terangan, tetapi dalam pembegalan ada unsur sembunyi-sembunyinya, yaitu sembunyinya para pelaku dari penguasa untuk keamanan dirinya. Dan karena inilah pencuri tidak dikatakan pembegalan kecuali dengan adanya batasan-batasan, maka

\footnotetext{
${ }^{9}$ Kitab Undang-Undang Hukum Pidana.

10 Sugandhi, Hukum Pidana Materiil (Jakarta: Sinar Grafika 2002), 387.

${ }^{11}$ Sayid Syabiq, Fiqh Sunnah IX (Bandung: Alma'arif, 1990), 43.
} 
dikatakanlah "pembegalan" atau pencurian besar, seandainya dikatakan pencurian saja pembegalan tidak dapat dipahami dari padanya. Keharusan memberi batas batas itu ada sebagian ciri-ciri majâz. ${ }^{12}$

Selanjutnya dijelaskan bahwa jarîmah hirâbah, sekalipun dinamakan pencurian besar tetapi tidak sama persis dengan pencurian. Pencurian adalah mengambil barang-barang atau harta dengan sembunyi-sembunyi, sedang hirâbah adalah keluar untuk mengambil harta dengan cara kekerasan, maka unsur yang pokok dari pencurian adalah mengambil harta secara nyata, sedang unsur pokok hirâbah adalah keluar untuk mengambil harta baik pengambilan harta itu terwujud atau tidak. Pengertian pembegal adalah merebut sesuatu atau barang orang lain secara paksa dan menakut-nakuti, sewaktu-waktu disertai penganiayaan atau membunuh pemilik barang tersebut. ${ }^{13}$

Para fuqaha berbeda pendapat dalam mendefinisikan jarimah perampokan (hirâbah) sebagaimana terlihat di bawah ini:

1. Pendapat Hanafiyah:

Hirâbah adalah ke luar untuk mengambil harta dengan jalan kekerasan yang realisasinya menakut-nakuti orang yang lewat di jalan, atau mengambil harta, atau membunuh orang.

2. Pendapat Syafi'iyah:

Hirâbah adalah ke luar untuk mengambil harta, atau membunuh, atau menakut-nakuti, dengan cara kekerasan, dengan berpegang kepada kekuatan, dan jauh dari pertolongan ( bantuan).

3. Pendapat Malikiyah:

Hirâbah adalah mengambil harta dengan tipuan (taktik), baik menggunakan kekuatan atau tidak.

4. Pendapat Hanabilah:

Hirâbah adalah orang yang mengambil harta orang lain secara terang-terangan dipadang pasir dengan menggunakan senjata.

5. Pendapat Zhahiliyah:

Perampok adalah orang yang melakukan tindak kekerasan dan mengintimidasi orang yang lewat, serta melakukan perusakan di muka bumi.

\footnotetext{
${ }^{12}$ Abdul Qadir Audah, at-Tashrî’ al-Jinâ'iy al-Islâmiy (Beirut: Dâr al-Kitâb al-Arabiy, Juz II), 638.

${ }^{13}$ Soedarsono, Pokok-Pokok Hukum Islam (Jakarta: Rineka Cipta, 1998), 547.
} 


\section{Unsur-unsur Pencurian dengan Kekerasan (Hirâbah)}

\section{Unsur umum.}

a. al-Rukn al-Shar'iy, yaitu adanya nash yang melarang perbuatanperbuatan tertentu yang disertai ancaman hukuman atas perbuatan jarîmah. Unsur ini dikenal dengan unsur formal.

b. al-Rukn al-Mâddiy, yaitu adanya unsur perbuatan yang berbentuk jarîmah, baik berupa melakukan perbuatan yang dilarang atau meninggalkan perbuatan yang diharuskan. Unsur ini dikenal dengan unsur material.

c. al-Rukn al-Adabiy, yaitu pelaku kejahatan adalah orang yang dapat memahami taklif, dalam artian pelaku kejahatan adalah mukallaf. Sehingga pelaku kejahatan dapat dituntut atas kejahatan yang mereka lakukan. Unsur ini dikenal dengan istilah unsur moral.

\section{Unsur Khusus}

Yaitu, Unsur yang hanya berlaku di dalam satu jarîmah dan tidak sama dengan unsur khusus jarîmah lainnya, adapun di dalam tindak pidana hirâbah unsur khususnya adalah:

a. Lokasi hirâbah yang dilakukan oleh pelakunya harus di tempat yang jauh dari tempat keramaian. Semisal di padang rumput yang jauh, di gunung, atau tempat yang sangat jauh dari lokasi penduduk. Jika tindakan itu dilakukan di tempat keramaian, maka namanya bukan tindak pidana hirâbah, akan tetapi perampasan biasa, sebab yang disebut dengan hirâbah adalah penyamunan, atau perampokan yang dilakukan di jalan-jalan. Bila mereka melakukan tindakan pembunuhan, perampasan harta, dan teror di tempat-tempat keramaian, maka tindakan mereka dianggap sebagai hirâbah dan berhak dijatuhi sanksi had. Ini adalah pendapat mayoritas ulama fiqh, Abu Hanifah, Abu Tsaur, dan lain-lain.

b. Pelaku membawa senjata yang dapat digunakan untuk membunuh, semisal, pedang, senapan, golok, dan lain-lain yang bisa menghilangkan nyawa orang lain. Imam Syafi'i dan Abu Tsaur menjelaskan bahwa jika mereka telah menggunakan tongkat-tongkat atau batu-batu, maka mereka sudah termasuk dalam memanggul senjata juga. 
c. Dilakukan dengan cara terang-terangan. Mereka merampas harta dengan paksa dan terang-terangan, dan biasanya mereka memiliki markas. Jika mereka mengambil harta dengan cara sembunyisembunyi mereka disebut surâq (pencuri-pencuri). Jika mereka merampas kemudian melarikan diri, mereka disebut penjambret atau perampok.

\section{Hukum Pidana Islam bagi Pencurian dengan Kekerasan}

Mengenai hukuman tindak pidana hirâbah sudah dijelaskan oleh shara' dan terdapat dalam surat al-Maidah ayat 33. Di dalam ayat ini menerangkan bahwa sesungguhnya pembalasan yang adil dan setimpal terhadap orang-orang yang memerangi Allah dan RasulNya dan yang berkeliaran membuat kerusakan di bumi yaitu melakukan pembunuhan, perampokan, pencurian dengan menakut-nakuti masyarakat, hanyalah mereka dibunuh tanpa ampun jika mereka membunuh tanpa mengambil harta, atau disalib setelah dibunuh jika mereka merampok dan membunuh, atau dipotong tangan kanan dan kaki kiri mereka dengan cara bertimbal balik jika mereka merampas harta tanpa membunuh, atau dibuang dari negeri tempat kediamannya yakni dipenjarakan jika mereka tidak merampok harta dan hanya menakut-nakuti masyarakat. Hukuman itu dilaksanakan agar menjadi pelajaran bagi yang lain, sekaligus menentramkan masyarakat umum bahwa penjahat telah tiada. ${ }^{14}$

Hukuman yang diberikan kepada pelaku tindak pidana hirâbah merupakan suatu penghinaan untuk mereka di dunia, sehingga selain mereka yang tadinya bermaksud jahat atau orang lain yang ingin melakukan kejahatan yang sama akan tercegah untuk melakukan tindakan tersebut. Selain hukuman di dunia mereka juga akan menerima hukuman di akhirat jika mereka tidak bertaubat, hukuman di akhirat berupa siksaan yang sangat besar.

Hukuman yang mereka terima belumlah habis, karena di akhirat perkaranya akan dibuka lagi dan akan diterimanya azab yang pedih. ${ }^{15}$ Ini membuktikan bahwa dosa orang-orang ini sangatlah besar. Di atas dunia mereka membuat keonaran, kerusakan dan menimbulkan ketidaktentraman bagi masyarakat sehingga mereka dihukum dengan

\footnotetext{
${ }^{14} \mathrm{M}$. Quraish Shihab, Tafsir al-Misbah "Pesan Kesan dan Keserasian al-Qur'an" (Jakarta: Lentera Hati, 2001), 78.

${ }^{15}$ Hamka, Tafsir al-Azhar, Juz VI (Jakarta: Pustaka Panjimas, 1982), 297.
} 
cara yang setimpal sesuai dengan hak-hak manusia, begitu juga di akhirat dia akan menerima balasan lagi karena yang diperangi oleh mereka adalah Allah dan Rasul-Nya.

Adanya hukuman yang telah mereka terima karena perbuatannya di dunia ini bukan berarti hukuman mereka berhenti di sini, melainkan di akhirat nanti perkaranya akan dibuka kembali dan akan diterimanya adzab yang sangat pedih. Ini bisa dijadikan bukti yang sangat otoritatif bahwa perbuatan dan dosa-dosa mereka memang sangat besar, yakni mengenai dibunuhnya mereka dan disalibnya mereka serta tangan dan kaki mereka dipotong secara bersilang serta dibuangnya mereka dari negara tempat tinggalnya, hal tersebut merupakan kehinaan bagi mereka di mata manusia dalam kehidupan dunia in. ${ }^{16}$ Hukuman pada ayat ini ditetapkan sedemikian berat, karena dari segi gangguan keamanan yang dimaksud itu selain ditujukan kepada umum juga kerap kali mengakibatkan pembunuhan, perampasan, pengrusakan dan lain-lain. Oleh sebab itu kesalahan-kesalahan ini oleh siapapun tidak boleh diberi ampunan.

Orang-orang yang mendapat hukuman sebagaimana dimaksud pada ayat ini selain dipandang hina di dunia, mereka di akhirat nanti diancam dengan siksa yang amat besar. ${ }^{17} \mathrm{Di}$ atas dunia ini mereka mengacau lalu dihukum secara setimpal, dan di akhirat akan diterimanya hukuman lagi karena yang diperanginya adalah Allah dan Rasul. Namun bagi mereka yang mendapatkan hukuman potongan tangan dan kaki yang berselang-seling dan yang dihukum dengan cara diasingkan dan masih hidup, maka mereka masih mempunyai kesempatan untuk bertaubat kepada Allah untuk menghindari adzab yang sangat pedih di akhirat kelak. Ketahuilah bahwa sesungguhnya Allah Maha Pengampun.

Para ulama berbeda pendapat tentang hukuman untuk jarîmah hirâbah. Menurut Imam Abu Hanifah, Imam Syafi'i, Imam Ahmad, dan Syiah Zaidiyah, hukuman untuk pelaku perampokan itu berbeda-beda sesuai dengan jenis yang dilakukannya. Sebagaimana telah diuraikan di atas. Bentuk-bentuk jarîmah hirâbah itu ada empat macam, yaitu :

1. Menakut-nakuti orang yang lewat, tanpa membunuh dan mengambil harta;

\footnotetext{
${ }^{16}$ Al-Imam Abul Fida Ismail Ibnu Kasir Ad-Dimasyqi, Tafsîr Ibn Kathîr, Cet II (Bandung: Sinar Baru Algensindo, 2003), 413.

${ }^{17}$ Muhammad Nawawi Al-Jawi, Tafsîr Al-Munîr (Al-Haramain Jaya Indonesia, 2009), 202.
} 
2. Mengambil harta tanpa membunuh;

3. Membunuh tanpa mengambil harta;

4. Mengambil harta dan membunuh orangnya.

Menurut mereka, untuk masing-masing perbuatan tersebut diterapkan hukuman tertentu yang diambil dari alternatif hukuman yang tercantum dalam surat al-Maidah ayat 33 .

Menurut Imam Malik dan Zhahiriyah, hukuman untuk pelaku perampokan itu diserahkan kepada hakim untuk memilih hukuman mana yang lebih sesuai dengan perbuatan dari alternatif hukuman yang tercantum dalam Surah al-Maidah ayat 33 tersebut. Hanya saja Imam Malik membatasi pilihan hukuman tersebut untuk selain pembunuhan. Untuk tindak pidana pembunuhan maka pilihannya hanya dibunuh dan disalib. Sementara Zhahiriyah memberikan kebebasan penuh kepada hakim untuk memelih hukuman apa saja yang sesuai menurut pandangannya dengan perbuatan apa pun dari keempat jenis perbuatan tersebut. $^{18}$

Adapun yang menjadi perbedaan tersebut adalah perbedaan

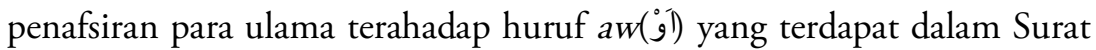
al-Maidah ayat 33, yang berbunyi:

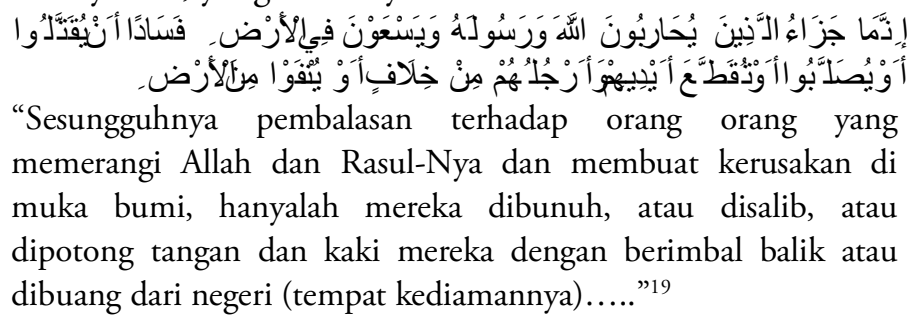

Jumhur ulama berpendapat bahwa huruf $a w\left(w^{\circ}\right)$ dalam ayat tersebut dimaksudkan untuk bayân (penjelasan) dan tafsîl (rincian). Dengan demikian, menurut mereka hukuman-hukuman tersebut diterapkan sesuai dengan berat ringannya perbuatan (jarîmah) yang dilakukan oleh pelaku perampokan. Imam Malik dan Zhahiriyah berpendapat bahwa huruf aw $\left({ }^{\circ}(1)\right.$ dalam surat al-Maidah ayat 33 dimaksudkan untuk takhyîr (pilihan). Dengan demikian, menurut mereka ayat tersebut mengandung arti bahwa hakim diberi kebebasan untuk memilih hukuman yang dipandangnya paling tepat dan sesuai

\footnotetext{
${ }^{18} \mathrm{Abdul}$ Qadir Audah, al-Tashrî̀ al-Jinâ'iy al-Islâmiy, 647.

19 T.M. Hasbi Ash-Shiddiqi, dkk., Al-Quran dan Terjemahanya (Madinah: Maujamma' Khadim AlHaramain, 1411), 164.
} 
dengan jenis jarîmah perampokan yang dilakukan oleh pelaku. Hanya saja Imam Malik membatasi pemilihan hukuman untuk tindak pidana pembunuhan, antara hukuman mati dan salib. Alasannya adalah karena pada awalnya setiap pembunuhan hukumannya adalah dibunuh (hukuman mati), sehingga tidaklah tepat apabila tindak pembunuhan dalam perampokan dihukum dengan potong tangan dan kaki atau pengasingan. Sementara Zhahiriyah dalam menerapkan ayat tersebut menganut khiyâr mutlaq sehingga hakim diberi kebebasan penuh untuk memeilih hukuman-hukuman tersebut, guna diterapkan pada jenis perbuatan perampokan yang dilakukan oleh pelaku. ${ }^{20}$

Terdapat beberapa hukuman bagi pelaku hirâbah, sebagaimana berikut ini:

1. Hukuman untuk Menakut-nakuti

Hukuman untuk jenis tindak pidana perampokan yang pertama ini (menakut-nakuti) adalah pengasingan (al-nafy). Pendapat ini dikemukakan oleh Imam Abu Hanifah dan Imam Ahmad. Alasannya adalah firman Allah dalam Surah al-Maidah ayat 33:

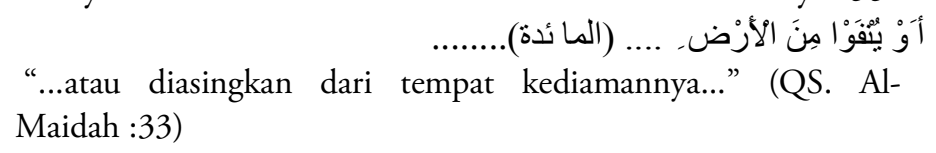

Adapun menurut Imam Syafi'i dan Syi'ah Zaidiyah, hukumannya adalah ta'zîr atau pengasingan, karena kedua jenis hukuman ini dianggap sama. ${ }^{21}$ Pengertian pengasingan (al-nafy) tidak ada kesepakatan di kalangan para ulama. Menurut Malikiyah, pengertian pengasingan (al-nafy) dengan dipenjarakan, tetapi tidak selalu di luar daerah terjadinya perampokan. Pendapat yang râjih dalam mazhab Syafi'i mengartikan pengasingan (al-nafy) dengan penahanan (al-habs), baik di daerahnya sendiri, tetapi lebih utama di daerah lain. Imam Ahmad berpendapat bahwa pengertian pengasingan (al-nafy) adalah pengusiran pelaku dari daerahnya, dan ia tidak diperbolehkan kembali sampai ia jelas telah bertaubat. ${ }^{22}$

Lamanya penahanan menurut Imam Abu Hanifah, Imam Malik, dan Imam Syafi'i tidak terbatas. Artinya, tidak ada batas waktu tertentu untuk penahanan seorang pelaku perampokan. Oleh

\footnotetext{
${ }^{20} \mathrm{Abdul}$ Qadir Audah, al-Tashrî́ al-Jinâ'iy al-Islâmiy, 64.

${ }^{21}$ Ibid., 647.

22 Ibid., 648-649.
} 
karena itu, ia tetap dipenjara sampai ia betul-betul bertaubat, dan tingkah lakunya menjadi baik. Pendapat itu merupakan pendapat yang râjih di kalangan Hanabilah. Sebagian ulama Hanabilah berpendapat bahwa masa pengasingan untuk pelaku perampokan adalah satu tahun, dengan mengiyaskannya kepada hukuman dalam jarîmah zina.

2. Hukuman untuk Mengambil Harta tTanpa Membunuh

Apabila jenis perampokan hanya mengambil harta tanpa membunuh, maka menurut Imam Abu Hanifah, Imam Syafi'i, Imam Ahmad, dan Syi'ah Zahidiyah, hukumannya adalah dipotong tangan dan kakinya dengan bersilang yaitu dipotong tangan kanan dan tangan kirinya. Mereka beralasan dengan firman Allah dalam Surah al-Maidah ayat 33:

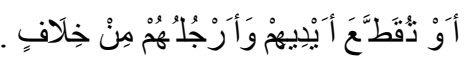

“..... atau dipotong tangan dan kakinya dengan bertimbal balik...” (QS. Al-Maidah:33)

Imam Malik berpendapat, bahwa sesuai dengan penafsiran

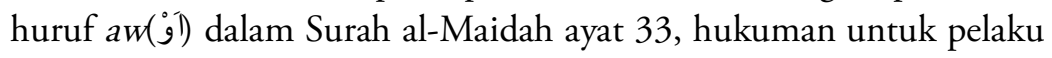
perampokan dalam pengambilan harta ini diserahkan kepada hakim untuk memelih hukuman-hukuman yang terdapat dalam Surah alMaidah ayat 33, asal jangan pengasingan.

3. Hukuman untuk Membunuh tanpa Mengambil Harta

Apabila pelaku perampokan hanya membunuh korban tanpa mengambil hartanya, menurut Imam Abu Hanifah, Imam Syafi'i, dan satu riwayat dari Imam Ahmad, hukumannya adalah dibunuh (hukuman mati) sebagai hukamn had tanpa disalib. Sementara menurut riwayat yang lain dari Imam Ahmad dan salah satu pendapat dari Syi'ah Zaidiyah di samping hukuman mati, pelaku juga harus disalib. $^{23}$

4. Hukuman untuk Membunuh dan Mengambil Harta

Apabila pelaku perampokan membunuh korban dan mengambil hartanya, menurut Imam Syafi'i, Imam Ahmad, Syi'ah Zahidiyah, Imam Abu Yusuf, dan Imam Muhammad dari kelompok Hanafiyah, hukumannya adalah dibunuh (hukuman mati) dan disalib, tanpa dipotong tangan dan kaki. Sedangkan Imam Abu Hanifah berpendapat bahwa dalam kasus ini hakim diperbolehkan

${ }^{23}$ Ibid., 652. 
untuk memilih dari salah satu dari tiga alternatif hukuman: pertama, potong tangan dan kaki, kemudian dibunuh atau disalib, kedua, dibunuh tanpa disalib dan tanpa potong tangan dan kaki, dan ketiga, disalib kemudian dibunuh.

\section{Teori Penggabungan Hukuman menurut Hukum Pidana Islam}

Dalam hukum pidana Islam, teori tentang bergandanya hukuman sudah dikenal di kalangan fuqaha, tetapi teori tersebut dibatasi pula dengan dua teori yang lain, yaitu teori saling melengkapi (al-tadâkhul) dan teori penyerapan (al-Jab).

a. Teori saling melengkapi ( Al-Tadâkhul)

Menurut teori ini, ketika terjadi gabungan jarîmah, maka hukuman-hukumannya saling melengkapi, sehingga oleh karenanya itu semua perbuatan tersebut dijatuhi satu hukuman, seperti kalau ia memperkuat perbuatan.

b. Teori Penyerapan (Al-Jab)

Yaitu menjatuhkan suatu hukuman, dimana hukumanhukuman yang lain tidak dapat dijatuhkan. Hukuman tersebut dalam hal ini tidak lain adalah hukuman mati, dimana pelaksanaannya dengan sendirinya menyerap hukuman-hukuman lain. Teori ini dikemukakan oleh beberapa ulama diantaranya Imam Malik, Abu Hanifah, dan Imam Ahmad.

c. Teori Percampuran (al-Mukhtalat)

Teori percampuran ini dimaksudkan untuk mengatasi kelemahan-kelemahan dari dua metode sebelumnya yaitu teori al-jab (penyerapan) dan teori al-tadâkhul (saling memasuki), yaitu dengan cara menggabungkan keduanya dan mencari jalan tengahnya. Sebagaimana yang telah disebutkan di awal bahwa hukum Islam dalam menggunakan kedua teori tersebut tidak secara mutlak. Dalam teori percampuran ini langkah yang dilakukan yakni dengan membatasi kemutlakan dari dua teori sebelumnya. Penggabungan hukuman boleh dilakukan namun tidak boleh melampaui batas tertentu. Tujuan daripada pemberian batas akhir ini bagi hukuman ialah untuk mencegah hukuman yang terlalu berlebihan. 


\section{Pembuktian Tindak Pidana Hirâbah}

Ulama fiqh sepakat menyatakan bahwa tindakan pidana hirâbah adalah merupakan salah satu tindak pidana yang proses pembuktiannya harus dilakukan melalui gugatan korban pidana tersebut pada hakim. Untuk itu pihak korban harus dapat membuktikan tindak pidana ini, adapun alat bukti yang digunakan untuk tindak pidana hirâbah ini adalah kesaksian dan pengakuan. Alat bukti saksi yang diajukan itu adalah dua orang laki-laki, adapun untuk pembuktian melalui pengakuan, menurut jumhur ulama cukup satu kali pengakuan saja, karena seseorang tidak mungkin mengakui suatu perbuatan yang tidak dilakukannya. Namun ulama Mazhab Hambali dan Imam Abu Yusuf mengatakan pengakuan itu harus dilakukan sebanyak dua kali. ${ }^{24}$

\section{Pengecualian Hukuman terhadap Tindak Pidana Hirâbah}

Hukuman yang ada dalam tindak pidana hirâbah dapat terhapus karena sebab-sebab yang menghapuskannya, hal ini sudah dijelaskan dalam Q.S. al-Maidah ayat 34, yang artinya:

"Kecuali orang-orang yang bertaubat (di antara mereka) sebelum kamu dapat menguasai (menangkap) mereka; maka ketahuilah bahwasanya Allah Maha Pengampun lagi Maha Penyayang". (QS.

Al-Maidah: 34)

Di dalam ayat ini terdapat pengecualian bagi mereka yang insyaf dan bertaubat kepada Allah sebelum tertangkap. Dia bertaubat dengan sebenar-benarnya taubat, tidak bercampur lagi dengan gerombolan penjahat itu dan menarik diri dari kelompoknya serta betul-betul dia taubah nasûhah. Tentu saja bukti taubat itu harus ditunjukkannya, yaitu dengan menyerahkan diri kepada yang berkuasa, mengakui kesalahannya dan mulai memperbaiki hidup. Maka hukuman-hukuman itu bolehlah tidak dilakukan lagi terhadap dirinya, setelah hakim menyelidiki bahwa telah benar taubatnya, baik taubat sendiri maupun dengan semuanya. Jika hakim melihat dan menimbang bahwa taubat mereka telah benar, maka hukuman tidak dijatuhkan lagi kepada mereka. Tetapi harta benda orang yang telah mereka rusak dan rampas harus dan wajib diganti. ${ }^{25}$

\footnotetext{
${ }^{24} \mathrm{http}: / /$ mahathir71.blogspot.com/2011/12/hukum-pidan-islam-fiqh-jinayah-hirabah.html/ diakses 29 Juni 2013.

${ }^{25}$ Sayyid Qutb, Tafsîr Fî Zhilâlal-Qur'ân (Jakarta: Gema Insani, 2004), 39.
} 
Bila perampoknya bertobat setelah ditangkap, maka taubatnya tidak dapat menghapuskan hukuman, baik hukuman yang berkaitan dengan hak hamba. Hal ini disebabkan karena:

1. Taubat sebelum ditangkap itu adalah taubat yang ikhlas, yakni muncul dari hati nurani untuk menjadi orang yang benar. Sedangkan taubat setelah ditangkap, pada umumnya takut terhadap ancaman hukuman yang dikenakan kepadanya.

2. Taubat sebelum ditangkap muncul karena kecenderungan perampok itu untuk meninggalkan perbuatan yang membawa kerusakan di muka bumi, sedangkan taubat setelah ditangkap prinsip kecenderungan ini tidak tampak karena tidak ada kesempatan lagi baginya untuk mengubah atau melestarikan tingkah laku jahatnya.

\section{Pertimbangan Hukum Hakim Pengadilan Negeri Sidoarjo dalam Putusan tentang Pencurian dengan Kekerasan}

Bahwa pada awalnya, terdakwa Sugik Ais. Koplak, terdakwa Buamat dan Agus (DPO) berkumpul di pertokoan sebelah Utara Pom Bensin Pasar Larangan Sidoarjo Jawa Timur, berunding mencari sasaran namun sasaran belum ada selanjutnya terdakwa Sugik, terdakwa Buamat dan Agus (DPO) meninggalkan pertokoan tersebut dengan naik sepeda motor berboncengan tiga menuju ke arah Selatan melewati Jalan Raya Pasar Larangan sebelah Barat, kemudian datanglah korban Khoirul Anwar dengan arah yang sama mengendarai sepeda motor Honda Supra Vit wama orange hitam dengan nomor polisi W-6072-NV seorang diri, lalu korban diikuti terus oleh terdakwa Sugik, terdakwa Buamat dan Agus (DPO) sesampainya di pertigaan dekat palang Kereta Api berbelok ke Timur langsung korban dipotong oleh Agus (DPO) sedangkan terdakwa Sugik dan terdakwa Buamat turun dari sepeda motor langsung menggertak korban Khoirul Anwar dan mengambil helm tutup kepala korban Khoirul Anwar untuk dipukulkan kearah korban Khoirul Anwar sehingga mengenai bagian kepala, lalu terdakwa Buamat juga ikut memukul badan korban dengan menggunakan tangan kosong berkalikali, atas kejadian tersebut korban merasa kesakitan dan ketakutan sehingga korban meninggalkan sepeda motor tersebut dalam keadaan kunci kontak masih menempel di sepeda, lalu sepeda tersebut diambil oleh terdakwa, Sugik, berboncengan dengan terdakwa, Buamat, menuju 
ke tempat kos terdakwa, Sugik, untuk menyimpan sepeda motor tersebut sedangkan.

Agus melarikan diri dengan menggunakan sepeda motor yang dipergunakan berboncengan tiga, esok harinya terdakwa Sugik danterdakwa Buamat didatangi oleh petugas polisi sehingga kedua terdakwa beserta dengan barang buktinya dibawa ke Polsek Candi guna pengusutan lebih lanjut. Akibat dari kejadlan tersebut saksi korban mengalami nyeri pada kepala bagian belakang sesual dengan hasil visum et repertum Nomor : 445/1562/404.6.812012 tanggal 07 Oktober 2012 yang ditandatangani oleh dr.Wahyu Bhakti. P dokter pada RSUD Kabupaten Sidoarjo dengan kesimpulan kelainan tersebut disebabkan kekerasan dengan benda tumpul.

Di pengadilan, Sugik dan Buamat dinyatakan terbukti bersalah secara sah dan meyakinkan melakukan tindak pidana "pencurian dengan kekerasan" sebagaimana diatur dan diancam dalam dakwaan pasa; 365 ayat (2) ke-1 dan Ke-2 KUHP sebagaimana dalam dakwaan kedua Jaksa Penuntut Umum; oleh karena itu kepada terdakwa I Sugik Als Koplak dan terdakwa II Buamat dengan pidana penjara selama 3 (tiga) tahun dikurangi selama para terdakwa di tahanan dan barang Bukti berupa: 1 (satu) unit sepeda motor Honda supra fit warna orange hitam No.pol:W-6072-NV; 1(satu) buah helm penutup kepala warna hitam dikembalikan kepada Khoirul Anwar dan menetapkan agar para terdakwa membayar biaya sebesar Rp. 2.500,- (Dua Ribu Lima ratus rupiah).

Dalam memutuskan perkara pencurian dengan kekerasan yang dilakukan Sugik dan Buamat, hakim menggunakan pertimbangan sebagaimana berikut:

Menimbang bahwa, untuk mempersingkat uraian putusan, maka segala sesuatu yang termuat dalam Berita Acara persidangan dianggap telah tercantum pada putusan ini;

Menimbang, bahwa berdasarkan keterangan saksi-saksi, keterangan para terdakwa dan bukti surat serta barang bukti yang satu dengan lainnya saling bersesuaian,maka diperoleh fakta hukum sebagai berikut:

1. Bahwa,para terdakwa pada hari Minggu tanggal 7 Oktober 2012 pada pukul 1.15 pagi di sebelah barat terminal pasar larangan desa larangan Kec.Candi Kab. Sidoarjo telah mengambil 1 unit sepeda motor 
Honda Supra Fit warna orange No.Pol: W-6072-NV milik korban Khoirul Anwar-

2. Bahwa, terdakwa I sebelum mengambil sepeda motor milik korban terlebih dahulu memukul kepala korban dengan menggunakan helm sedangkan terdakwa II sehingga korban mengalami nyeri di kepala dan punggung;

3. Bahwa, terdakwa I dan terdakwa II mengambil sepeda motor korban dengan kunci yang masih menggantung dikunci kontak motor tersebut setelah motor tersebut ditinggal pergi oleh korban;

4. Bahwa, sepeda motor korban dititipkan terdakwa I di kost-kostan terdakwa II yang rencananya akan dijual tetapi sebelum dijual para terdakwa sudah ditangkap polisi;-

5. Bahwa, para terdakwa mengambil mobil tersebut tanpa seijin pemiliknya;

Menimbang, bahwa selanjutnya Majelis akan mempertimbangkan apakah berdasarkan fakta-fakta hukum tersebut diatas, Terdakwa dapat dinyatakan telah melakukan tindak pidana sebagaimana dakwaan penuntut umum yang didakwakan kepadanya;

Menimbang, bahwa untuk menyatakan seseorang telah melakukan suatu tindak pidana, maka perbuatan orang tersebut haruslah memenuhi seluruh unsur-unsur dari tindak pidana yang didakwakan kepadanya;

Menimbang, bahwa terdakwa oleh Jaksa Penuntut Umum didakwa dengan dakwaan melanggar Pasal 365 ayat (2) ke-1 dan ke-2 KUHP;

Menimbang,bahwa_dalam rumusan Pasal 365 ayat (2) ke-1 dan ke-2 KUHP mengandung kwalifikasi pasal 362 KUHP tentang pencurian untuk itu maka akan dipertimbangkan terlebih dahulu kwalifikasi tersebut yang unsur-unsurnya sebagai berikut: 1. Barang Siapa; 2. Mengambil Barang sesuatu yang seluruhnya atau sebagian kepunyaan orang lain; 3 . Dengan maksud untuk dimiliki secara melawan Hukum:

\section{Unsur "Barang Siapa"}

Menimbang, bahwa kata barang siapa menunjuk kepada orang yang apabila orang tersebut terbukti memenuhi semua unsur dari tindak pidana yang dimaksudkan di dalam ketentuan pidana yang diatur dalam pasal 365 ayat (2) ke 1 dan ke-2 KUHP dan dapat 
diminta pertanggungjawabannya menurut hukum pidana, maka ia dapat disebut sebagai pelaku dari tindak pidana tersebut;

Menimbang, bahwa dipersidangan telah dihadapkan erdakwa I Sugik Alias Koplak dan terdakwa II Buamat dengan segenap identitasnya sebagaimana tersebut dalam surat dakwaan dan berdasarkan keterangan para saksi yang diakui oleh para terdakwa dipersidangan telah ternyata terdakwa I Sugik Alias Koplak dan terdakwa II Buamat sebagaimana dimaksud Jaksa Penuntut Umum sebagai para terdakwa dalam perkara ini dan bukan orang lain selain para terdakwa tersebut, yang selama persidangan nampak berkomunikasi, memahami dan menjawab dengan baik dan normal, secara keseluruhan sehingga ia dapat dikatakan sehat lahir maupun batin, oleh karena itu dianggap dapat bertanggungjawab;

Menimbang bahwa terdakwa terdakwa I Sugik Alias Koplak dan terdakwa II Buamat untuk dapat disebut sebagai pelaku tindak pidana dalam perkara ini apabila perbuatannya memenuhi segenap unsur dari pasal 365 ayat (2) ke 1 dan ke-2 KUHP dan oleh karena itu lebih lanjut Hakim akan mempertimbangkan unsur-unsur dari pasal barang siapa seperti terurai di bawah ini;

2. Mengambil Barang sesuatu yang seluruhnya atau sebagian kepunyaan orang lain;

Menimbang bahwa perbuatan mengambil barang yang disyaratkan dalam hal ini adalah adalah termasuk juga memindahkan barang yang mempunyai nilai dari suatu tempat lainnya dan barang tersebut dikuasai sepenuhnya secara nyata. Dalam pengertian secara meteriil mengambil adalah suatu tingkah laku yang disengaja pada umumnya dengan menggunakan jari-jari tangan yang kemudian diarahkan pada suatu benda, menyentuh, memegang, mengangkat, lalu membawa dan memindahkan ke tempat lain atau dalam kekuasaannya;

Menimbang bahwa berdasarkan keterangan saksi Khoirul Anwar dihubungkan dengan keterangan Para terdakwa yang dikaitkan dengan barang bukti yang diajukan dipersidangan telah ternyata Terdakwa I dan terdakwa II bersama Agus (DPO) pada tanggal 7 oktober 2012 sekitar pukul 1.15 pagi di barat terminal pasar larangan Desa Larangan Kecamatan Candi Kab. Sidoarjo telah memepet saksi khoirul Anwar sehingga saksi berhenti dan selanjutnya 
terdakwa I memukul kepala saksi dengan helm sedangkan terdakwa II memukul punggung korban sehingga saksi ketakutan kemudian meninggalkan 1 (satu) unit sepeda motor Honda Supra Fit warna orange No.Pol: W-6072-NV dengan kunci kontak masih menggantung pada sepeda motor yang kemudian oleh terdakwa I sepeda motor tersebut dibawa lari dan dititipkan dikost-kostan terdakwa II.Berdasarkan fakta-fakta hukum tersebut maka unsur Mengambil Barang sesuatu yang seluruhnya atau sebagian kepunyaan orang lain telah terpenuhi;

3. Dengan maksud untuk dimiliki secara melawan

Menimbang bahwa unsur ini memiliki pengertian bahwa dalam diri pelaku sudah terkandung suatu kehendak (sikap batin) untuk memiliki barang sesuatu agar menjadi miliknya seolah-olah ia adalah pemiliknya ataupun menguasai bagi dirinya benda-benda yang diambil dari penguasaan orang lain dengan cara bertentangan dengan hukum dan norma dalam masyarakat;

Menimbang bahwa berdasarkan keterangan para saksi dikaitkan dengan barang bukti yang saling berhubungan serta diakui oleh para terdakwa bahwa sebelum mengambil 1 unit sepeda motor milik korban terlebih dahulu terdakwa I memukul kepala korban sedangkan sedangkan terdakwa II memukul punggung korban dengan tujuan agar bisa menguasai sepeda motor milik korban dan setelah berhasil mengambil sepeda motor tersebut dititipkan dirumah kost-kostan terdakwa II yang rencananya akan dijual oleh para terdakwa;

Berdasarkan uraian tersebut Majelis Hakim berpendapat bahwa para terdakwa telah memiliki maksud untuk menguasai sepeda motor milik korban yang diketahuinya bahwa cara memiliki sepeda motor tersebut bertentangan dengan hukum dan norma dalam masyarakat sehingga unsur "Dengan maksud untuk di miliki secara melawan hukum" telah terpenuhi;

Menimbang, bahwa semua unsur kwalifikasi pencurian dalam pasal 362 KUHP telah terpenuhi maka kemudian Hakim akan mempertimbangkan unsur pemberat dalam pasal 365ayat (2) ke-1 dan ke-2 KUHP yang mana unsur-unsurnya adalah sebagai berikut: 1 . Didahului, disertai atau diikuti dengan kekerasan atau ancaman kekerasan terhadap orang dengan maksud mempersiapkan atau 
memudahkan pencurian; 2. Dalam sebuah rumah atau pekarangan yang tertutup atau di atas jalan umum atau diatas kereta api atau trem yang bergerak; 3. Dilakukan oleh dua orang bersama-sama atau lebih;

1. Didahului, disertai atau diikuti dengan kekerasan atau ancaman kekerasan terhadap orang dengan maksud mempersiapkan atau memudahkan pencurian;

Menimbang, bahwa unsur ini mengandung beberapa elemen unsur yang bersifat alternatif, yang artinya apabila salah satu elemen telah terpenuhi maka unsur ini telah terbukti dan elemen-elemen yang selebihnya tidak perlu lagi dipertimbangkan lebih lanjut;

Menimbang bahwa, dari fakta-fakta yang terungkap dalam persidangan perbuatan yang dilakukan oleh para Terdakwa lebih mendekati pada elemen "didahului dengan kekerasan terhadap orang dengan maksud memudahkan pencurian" maka Majelis Hakim akan mempertimbangkan elemen unsur dimaksud;

Menimbang,bahwa kekerasan dimaksud adalah mempergunakan tenaga atau kekuatan jasmani tidak kecil secara tidak syah sehingga berdasarkan keterangan saksi korban yang diakui oleh para terdakwa dikaitkan dengan bukti visum et repertum telah ternyata sebelum mengambil 1 unit sepeda motor Honda Supra Fit warna orange No.Pol: W-6072-NV milik saksi korban, para terdakwa telah melakukan pemukulan kepada korban sehingga korban mengalami nyeri dikepala dan sakit dipunggung serta hal mana diakui oleh para terdakwa bahwa tujuan memukul korban adalah untuk memiliki sepeda motor tersebut, sehingga Majelis Hakim berpendapat bahwa unsur ini telah terpenuhi;

2. Dalam sebuah rumah atau pekarangan yang tertutup atau diatas jalan umum atau diatas kereta api atau trem yang bergerak;

Menimbang bahwa, yang dimaksud dengan malam hari adalah masa antara matahari terbenam dan matahari terbit;

Menimbang, bahwa elemen unsur kedua yaitu sebuah rumah atau pekarangan yang tertutup atau diatas jalan umum atau diatas kereta api atau trem yang bergerak mengandung beberapa elemen unsur yang bersifat alternatif, yang artinya apabila salah satu elemen telah terpenuhi maka unsur ini telah terbukti dan elemen-elemen yang selebihnya tidak perlu lagi dipertimbangkan lebih lanjut; 
Menimbang bahwa, dari fakta-fakta yang terungkap dalam persidangan perbuatan yang dilakukan oleh para Terdakwa lebih mendekati pada elemen unsur "diatas jalan umum" maka Majelis Hakim akan mempertimbangkan elemen unsur dimaksud;

Menimbang bahwa yang dimaksud dengan "Diatas Jalan Umum" adalah jalan terbuka untuk lalu lintas umum yang sifatnya terbuka untuk umum termasuk di dalamnya jalan pejalan kaki,tepi jalan yang merupakan bagian dari jalan tersebut;

Menimbang bahwa berdasarkan fakta-fakta dipersidangan yang diperoleh dari keterangan para saksi yang saling berhubungan dengan keterangan terdakwa telah ternyata bahwa para terdakwa telah mengambil 1 unit sepeda motor Honda Supra Fit warna orange No.Pol: W-6072-NV milik korban Khoirul Anwar dilakukan pada pukul 1.15 wib pagi hari yang berdasarkan keterangan para saksi saat itu masih dalam keadaan gelap dan diterangi oleh penerangan cahaya lampu diatas jalan raya areal pasar larangan Desa Larangan Kec. Candi Kabupaten Sidoarjo tepat ditimur palang kereta api;

Menimbang berdasarkan pertimbangan tersebut Majelis Hakim berpendapat bahwa unsur ini telah terpenuhi;

3.. Dilakukan oleh dua orang bersama-sama atau lebih;

Menimbang bahwa yang dimaksud dengan dua orang atau lebih secara bersama ialah dua orang atau lebih dengan bersekutu yang terlibat dan bertanggungjawab atas timbulnya pencurian yang dilakukan secara turut serta dan mempunyai niat dan tujuan yang sama dalam suatu tindak pidana dan mempunyai peran masingmasing untuk memuluskan tindak pidana tersebut;

Menimbang bahwa, dari keterangan para saksi yang diakui oleh para terdakwa bahwa telah nyata para terdakwa dalam mengambil 1 (satu) unit sepeda motor Honda Supra Fit warna orange No.Pol: W-6072-NV dilakukan oleh para terdakwa dan Agus (DPO) yang bertujuan ingin memiliki dan menjual sepeda motor tersebut sehingga Majelis Hakim berpendapat bahwa para terdakwa dalam melakukan pencurian tersebut dilakukan secara bersama-sama yang mempunyai niat dan tujuan yang sama pula yaitu memperoleh hasil dari penjualan sepeda motor yang telah dicuri dengan demikian unsur ini telah pula terpenuhi; 
Menimbang, bahwa berdasarkan pertimbangan-pertimbangan tersebut Majelis Hakim berpendapat bahwa para Terdakwa telah terbukti secara sah dan meyakinkan bersalah melakukan tindak pidana sebagaimana diancam dalam pasal 365ayat (2) ke-1 dan ke-2 KUHP maka kepada para terdakwa harus dijatuhi pidana yang setimpal dengan perbuatannya/kesalahanya;

Menimbang, bahwa untuk menjatuhkan pidana terhadap diri terdakwa, maka perlu dipertimbangkan terlebih dahulu hal-hal yang memberatkan dan yang meringankan ;

Hal yang memberatkan :

- Perbuatan dakwa merugikan orang lain ;

- Perbuatan terdakwa sangat meresahkan masyarakat ;

Hal yang meringankan :

- Para Terdakwa mengakui terus terang dan menyesali perbuatannya;

- Para terdakwa tulang punggung keluarga;

- Para terdakwa belum sempat menikmati hasil kejahatannya;

Menimbang, bahwa dalam perkara ini terhadap diri para terdakwa telah dikenakan penahanan yang sah, maka masa penahanan tersebut harus dikurangkan seluruhnya dari pidana yang dijatuhkan ;

Menimbang, bahwa oleh karena para terdakwa ditahan dan penahanan terhadap diri terdakwa dilandasi alasan yang cukup, maka perlu ditetapkan agar terdakwa tetap berada dalam tahanan ;

Menimbang, bahwa terhadap barang bukti dalam perkara ini statusnya akan ditentukan sebagaimana tersebut dalam amar di bawah ini:

Menimbang, bahwa terdakwa terbukti bersalah maka dibebani untuk membayar biaya perkara ini;

Memperhatikan Pasal. 365 ayat (2) ke-1 dan ke-2 KUHP dan UU RI No. 8 tahun 1981 KUHAP serta peraturan lain yang berlaku dan bersangkutan;

M E N G A D I L I :

1. Menyatakan terdakwa I Sugik, terdakwa II Buamat terbukti secara sah dan meyakinkan bersalah melakukan tindak pidana : "Pencurian dengan kekerasan dalam keadaan memberatkan"; 
2. Menjatuhkan pidana atas diri terdakwa I Sugik, terdakwa II Buamat oleh karena itu dengan pidana penjara masing-masing selama 2 (Dua) Tahun;

3. Menetapkan lamanya para terdakwa di tahanan dikurangkan seluruhnya dari pidana yang dijatuhkan;

4. Menetapkan para terdakwa tetap berada dalam tahanan;

5. Menetapkan barang bukti dalam perkara ini berupa: 1(satu) unit sepeda motor Honda supra fit warna orange hitam No.pol:W-6072NV dan 1(satu) helm tutup kepala warna hitam dikembalikan kepada Khoirul Anwar

6. Membebankan kepada para terdakwa untuk membayar biaya perkara masing-masing sebesar Rp. 2.500,- (Dua ribu Lima Ratus Rupiah );

Demikianlah diputuskan pada hari: Rabu, tanggal 27 Februari 2013, oleh: Berlian Napitupulu .S.H. MHum sebagai Hakim Ketua, Saryana, S.H.,M.H., dan Bahuri, S.H., masing-masing sebagai Hakim Anggota, putusan mana diucapkan pada hari itu juga dalam sidang yang terbuka untuk umum oleh Hakim Ketua tersebut dengan didampingi oleh Hakim-Hakim Anggota dan dibantu oleh: I Nyoman Agus Hermawan SH., Panitera Pengganti pada Pengadilan Negeri Sidoarjo, dihadiri: Riski Candra Dewi,SH.MH, Jaksa Penuntut Umum pada Kejaksaan Negeri Sidoarjo dan dihadiri oleh para terdakwa.

\section{Analisis}

Pertimbangan hakim yang dijatuhkan Pengadilan Negeri Sidoarjo kepada terdakwa Sugik alias Koplak dan terdakwa Buamat mempertimbangkan unsur-unsur dalam pasal 362 dan pasal 365 ayat (2) Kitab Undang-Undang hukum Pidana sebagaimana yang dilakukan terdakwa yaitu:

a. Unsur Obyektif

1. Barang siapa

Subyek atau pelaku tindak pidana.

2. Mengambil

Membawa barang tersebut dari tempat asalnya ketempat lain, jadi barang tersebut harus dapat diangkat dan dipindahkan.

3. Barang

Memiliki arti terdapat barang yang diambil, adapun yang dimaksud barang adalah sesuatu yang harus bernilai. 
4. Seluruhnya atau sebagian milik orang lain

Barang tersebut milik pelaku tetapi merupakan milik orang lain seluruhnya atau sebagian.

b. Unsur Subjektif

1. Dengan maksud memiliki

Pelaku memiliki tujuan untuk memiliki bagi diri sendiri barang yang sejatinya merupakan kepunyaan orang lain.

2. Secara melawan hukum

Pelaku secara sadar dan telah mengetahui bahwa perbuatan mengambil yang dilakukan merupakan suatu yang dilarang oleh hukum.

Pertanggungjawaban pidana yang dijatuhkan pada para terdakwa adalah hukuman penjara selama 2 tahun. Hukuman tersebut sudah maksimal, hal ini dikarenakan korban hanya mengalami penganiayaan ringan serta para terdakwa mau mengembalikan barang curian tersebut.

Putusan Pengadilan Negeri Sidoarjo Nomor: 832/PID.B/2012/PN.Sda tentang kasus tindak pidana pencurian dengan kekerasan, menurut hukum pidana Islam dapat dikategorikan jarîmah hirâbah ringan, dalam hal kasus ini terdakwa melakukan jarimah hirâbah tipe 2 yaitu merampok tanpa membunuh, sehingga terdakwa bisa dikenai hukuman ta'zîr karena mempertimbangkan berbagai sudut pandang para ulama. Oleh karena itu, hukuman tersebut diserahkan pada ulil amri atau pemerintah.

\section{Simpulan}

Pertimbangan hakim yang dijatuhkan Pengadilan Negeri Sidoarjo kepada terdakwa Sugik alias Kolak dan terdakwa Buamat mempertimbangan unsur-unsur yang ada pada Kitab Undang-Undang Hukum Pidana di Republik Indonesia, sebagaimana kejahatan yang dilakukan oleh terdakwa. Pertanggungjawaban pidana bagi pelaku tindak pidana pencurian dengan kekerasan (Sugik dan Buamat) dijatuhi hukuman adalah hukuman pidana penjara selama 2 tahun, mengembalikan barang korban dan membayar denda persidangan.

Putusan Pengadilan Negeri Sidoarjo Nomor: 832/PID.B/2012/PN.Sda tentang tindak pidana pencurian dengan kekerasan, menurut hukum pidana Islam dapat dikategorikan dalam jarîmah hirâbah, sehingga terdakwa dihukum ta'zîr, dimana hukuman 
tersebut diserahkan kepada ulil amri (hakim). Macam hukuman ta'zîr dapat berupa hukuman mati, penjara, pengucilan, penyalipan, dera, dan ancaman.

Uraian diatas dapat disimpulkan bahwa pencurian dengan kekerasan tidak diperbolehkan di Indonesia. Hal ini karena meresahkan masyarakat dan menimbulkan ketakutan serta ketidakyamanan. Oleh karena itu, perlu ketegasan hukuman bagi yang melanggar agar dapat membuat efek jera bagi pelaku pencurian dengan kekerasan.

Sejalan dengan kesimpulan diatas, maka disarankan, hendaknya para hakim maupun calon hakim harus memiliki jiwa keadilan dan kecermatan dalam menjatuhkan hukum pada setiap perkara yang dihadapi, hukuman yang dijatuhkan harus mempunyai efek jera bagi pelaku kejahatan agar tidak terulang lagi ataupun bertambah maraknya kejahatan yang dapat merugikan orang lain serta masyarakat.

\section{Daftar Rujukan}

Dimasyqi (ad-), Al-Imam Abul Fida Ismail Ibnu Kasir. Tafsîr Ibn Kathîr. Cet II, Bandung: Sinar Baru Algensindo, 2003.

Djazuli, A. Fiqih Jinayah. Jakarta: Raja Grafindo Persada, 1996.

-------.. Fiqh Jinayah (Upaya Menanggulangi Kejahatan dalam Islam). Cet II, Jakarta: PT Raja Grafindo Persada, 1997.

Hamka. Tafsir al-Azhar, Juz VI. Jakarta: Pustaka Panjimas, 1982.

Hanafi, A. Asas-asas Hukum Pidana Islam. Jakarta: Bulan Bintang, 1993.

Ibnu dan Zainal Abidin Mas'ud. Fiqih Madzhab Syafi'i (Edisi Lengkap) Buku 2, Muamalat, Munakahat, Jinayat. Bandung: CV Pustaka Setia, 2007.

Jawi (al-), Muhammad Nawawi. Tafsîr Al-Munîr. Al-Haramain Jaya Indonesia, 2009.

Kansil, C.S.T. Pengantar Ilmu Hukum. Jakarta: Balai Pustaka, 1992.

Kementerian Agama RI. Al-Qur'an dan Terjemahnya. Jakarta: Widya Cahaya, 2011.

Leden, Marpaung. Asas Teori Praktik Hukum Pidana. Jakarta: Sinar Grafika, 2008.

Mahalli (al-), Imam Jalaluddin. Tafsir Jalalain. Jilid I, Bandung: Sinar Baru Algesindo, 2010. 
Moeljatno. Asas-asas Hukum Pidana. Jakarta: Rineka Cipta, 1985.

Kitab Undang-Undang Hukum Pidana. Jakarta: Bumi Aksara, 1996.

Munajat, Makhrus. Hukum Pidana Islam di Indonesia. Yogyakarta, Penerbit Teras, 2009.

Muslich, Ahmad Wardi. Hukum Pidana Islam. Jakarta: Sinar Grafika, 2005.

Na'im (an-), Abdullah Ahmad. Dekonstruksi Syari'ah. Yogyakarta: LkiS, 2001.

Qutb, Sayyid. Tafsîr Fî Zhilâl al-Qur'ân. Jakarta: Gema Insani, 2004.

RM, Soeharto. Hukum Pidana Materiil. Jakarta: Sinar Grafika, 1993.

Sabiq, Sayid. Fiqh Sunnah $I X-X$. Bandung: Al-Ma’arif, 1990.

Saleh, Ruslan. KUHP Dan Penjelasannya. Jakarta: Aksara Baru, 1987.

Santoso, Topo. Membumikan Hukum Pidana Islam. Jakarta: Gema Insani Press, 2003.

Waluyo, Bambang. Pidana dan Pemidanaan. Jakarta: Sinar Grafika, 2000.

Wirjono. Asas-Asas Hukum Pidana di Indonesia. Jakarta: Erisco, 1981.

http://mahathir71.blogspot.com/2011/12/hukum-pidana-Islam-fiqhjinayah-hirabah.html/ diakses 03 Juni 2013

Habibi. Perampokan dan Pencurian, dalam http://www.habibi_muah@yahoo.com/ diakses 02 Juni 2013 